\title{
SOSIALISASI MANAGEMENT / EMPLOYEE STOCK OPTION PROGRAM (MESOP) BAGI PENGURUS SERIKAT PEKERJA DI KABUPATEN KARAWANG DALAM RANGKA PENINGKATAN PARTISIPASI KEPEMILIKAN DAN KESEJAHTERAAN PEKERJA
}

\author{
${ }^{1 *}$ Holyness N. Singadimedja, ${ }^{2}$ Ema Rahmawati, ${ }^{3}$ Rai Mantili \\ Fakultas Hukum Universitas Padjadjaran, Bandung, Jawa Barat, Indonesia \\ Email : "holyness@unpad.ac.id
}

Manuskrip: Januari -2021; Ditinjau: Februari -2021; Diterima: Mei -2021; Online: Juli-2021; Diterbitkan: Juli-2021

\begin{abstract}
ABSTRAK
Management / employee stock option program di Indonesia merupakan program untuk peningkatan kesejahteraan pekerja menjadi hal yang penting untuk dipahami oleh tenaga kerja di Indonesia. Program MESOP atau ESOP merupakan suatu program perusahaan yang memungkinkan para karyawan untuk turut serta memiliki saham dari perusahaan tempat mereka bekerja. Tujuan dari program ini adalah sebagai sarana bagi perusahaan untuk memberikan apresiasi kepada karyawannya, serta dapat menciptakan keselarasan kepentingan antara pemegang saham perusahaan dengan manajemen dan karyawan perusahaan tersebut. Dalam pengabdian pada masyarakat ini akan memberikan sosialisasi mengenai Program MESOP yang dilaksankan oleh Tim Pengabdian Kepada Mayarakat (PPM) Fakultas Hukum Universitas Padjadjaran. Metode yang dipergunakan dalam kegiatan ini adalah diskusi terarah dengan sasaran Pengurus Serikat Pekerja di perusahaan-perusahan, pengurus Serikat Pekerja cabang Kabupaten Karawang, sehingga dapat memahami dan menjalankan program MESOP untuk peningkatan kesejahteraan Pekerja. Hasil Kegiatan Pengabdian Pada Masyarakat ini dapat memberikan tambahan pengetahuan dan pemahaman bagi pengurus serikat pekerja sehingga kedepannya dapat diajukan untuk masuk dalam ketentuan dalam perjanjian kerja bersama sebagai program yang dapat dijalankan oleh perusahaan dan pekerja.
\end{abstract}

\section{Kata Kunci: MESOP, Partisipasi Kepemilikan, Kesejahteraan Pekerja}

\section{PENDAHULUAN}

Banyaknya unjuk rasa yang dilakukan oleh kelompok-kelompok pekerja di berbagai daerah sejak dahulu sampai dengan saat ini secara umum memiliki tuntutan yang sama pada intinya, yaitu terkait permasalahan kesejahteraan dari pekerja di Indonesia. Kenyataan tersebut membutuhkan implementasi yang tegas dan konkret guna memenuhi kesejahteraan pekerja sebagaimana amanat dari UU Ketenagakerjaan. 
Dalam perkembangannya, dikenal Program Kepemilikan Saham oleh pekerja atau Employee Stock Ownership Program / ESOP yang dapat dikategorikan juga sebagai fasilitas yang diberikan oleh perusahaan kepada pekerjanya. ESOP merupakan salah satu bentuk kompensasi atau balas jasa yang diberikan perusahaan kepada pekerja. Faktor penting yang mendorong pekerja memiliki komitmen terhadap perusahaan tempatnya bekerja adalah kompensasi atau balas jasa yang diberikan oleh perusahaan. Kompensasi yang diberikan dapat berupa kompensasi finansial maupun non finansial. Kompensasi yang bersifat finansial dapat berbentuk upah/gaji, tunjangan bonus, dan juga berupa kepemilikan saham perusahaan oleh pekerja, sedangkan untuk kompensasi non finansial meliputi kesehatan, keamanan dan kenyamanan pekerja. Meskipun bonus merupakan sarana non gaji yang paling lazim digunakan perusahaan untuk memberi imbalan para pekerjanya, sesuai dengan survey dewan konferensi terhadap 520 perusahaan besar Amerika Serikat, pilihan untuk menerapkan ESOP merupakan cara terpopuler kedua.

Mengingat pentingnya program ESOP/MESOP terhadap kepentingan karyawan dan partisipasi pekerja dalam perusahaan, maka dilakukan pengabdian kepada masyarakat pada serikat pekerja di Kabupaten Karawang. Karawang merupakan salah satu daerah kabupaten di Jawa Barat. Daerah kabupaten ini berbatasan langsung dengan Bekasi, Bogor, dan tidak jauh dari Jakarta. Kabupaten Karawang dipilih menjadi lokasi pengabdian kepada masyarakat ini dengan alasan bahwa Kabupaten Karawang dikenal sebagai kota industri. Berdasarkan data yang dihimpun dari Disnakertrans Karawang, bahwa hingga 2018, jumlah pabrik yang beroperasi di kabupaten ini sebanyak 1.762 pabrik. Rinciannya, pabrik swasta sebanyak 787, PMDN sebanyak 269, PMA sebanyak 638, dan Joint venture tercatat sebanyak 58 pabrik. Karawang saat ini merupakan pusat pergerakan industri di Indonesia yang berhasil menarik pengusaha mancanegara.

Penyuluhan ini bertujuan memberikan pengetahuan kepada masyarakat khususnya para pekerja melalui pengurus serikat pekerja di Kabupaten Karawang bahwa adanya Program Kepemilikan Saham oleh pekerja, Direksi, dan Komisaris yang dilakukan melalui penawaran saham atau penawaran Opsi Saham dalam rangka kompensasi terhadap pekerja, Direksi, dan Komisaris, yang dapat menguatkan perusahaan dan meningkatkan kesejahteraan para pihak (pengusaha dan pekerja).

\section{METODE PELAKSANAAN}

Metode yang dipergunakan dalam penyuluhan hukum ini adalah diskusi terarah dengan peserta, diskusi ini diikuti oleh unsur yang berkepentingan yang terdiri pengurus Serikat pekerja di perusahaan dan pengurus serikat pekerja cabang Kabupaten Karawang, yang memiliki peran penting dalam meningkatkan kesejahteraan pekerja.

\section{HASIL PEMBAHASAN}

Pengumpulan data dilakukan sebelum sosialisasi dan setelah simulasi. Questioner terdiri dari 2 pertanyaan mengenai pengetahuan peserta khususnya 
serikat pekerja tentang MESOP, 4 pertanyaan tentang Hukum Ketenagakerjaan, Hukum Perusahaan, dan Penanaman Modal.

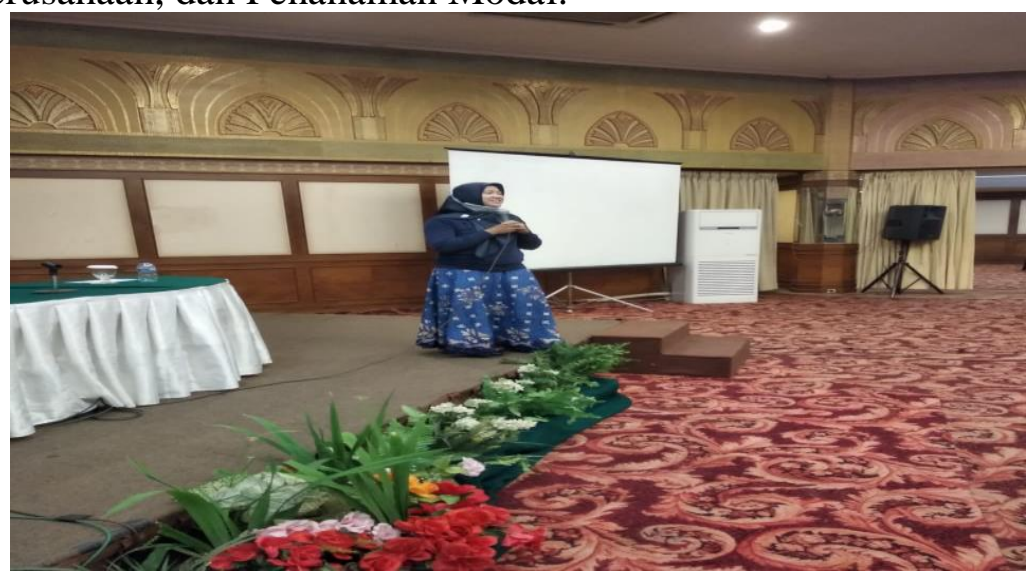

Gambar 1. Pemberian Materi Sosialisasi Program MESOP Sumber : Dokumetasi Tim

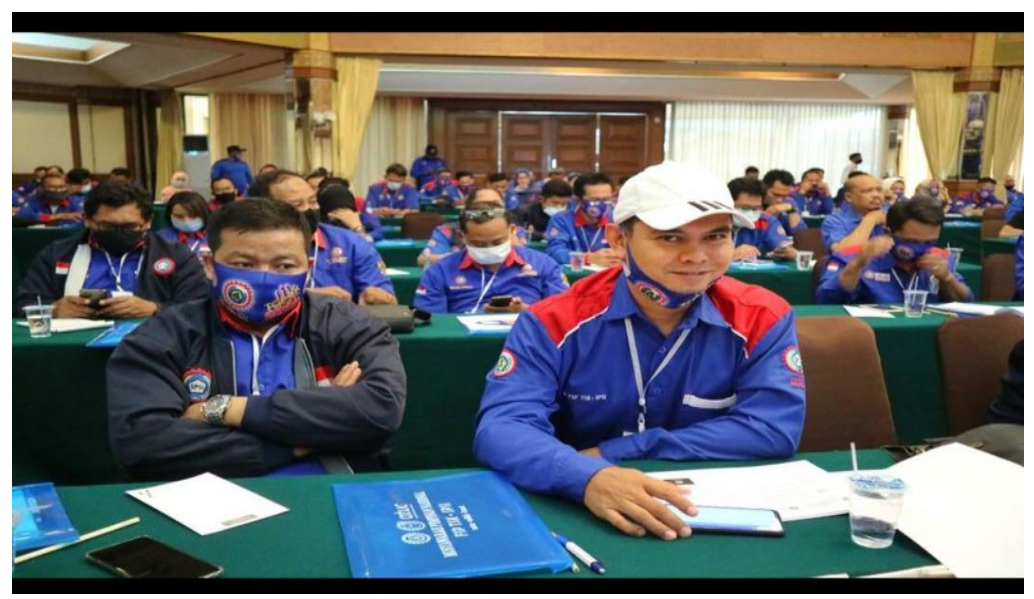

Gambar 2. Peserta PKM

Sumber : Dokumentasi Tim

Secara umum karena peserta merupakan pengurus serikat pekerja mereka telah mendapatkan pengetahuan mengenai Hukum Ketenagakerjaan, namun pemahaman terhadap Program MESOP dan Hukum Perusahaan belum begitu baik; permasalahan kesejahteraan pekerja yang selama ini diperjuangakan oleh Serikat Pekerja berupa Upah dan Pemberhentian Kerja /PHK, hanya 15 persen peserta pengabdian kepada masyarakat yang mengetahui dan memahami program MESOP dan Hukum Ketenagakerjaan.

Pada tahap diskusi setelah mendapatkan materi sosialisasi, peserta PKM secara umum telah memahami materi yang diberikan. Berdasarkan hasil evaluasi penilaian Questioner dan tanya jawab dalam sosialisasi, pengetahuan peserta mengenai Program MESOP dan hukum Perusahaan sangat sedikit sekali, Pengurus Serikat pekerja seharusnya lebih berpandangan kedepan, dengan membuat program kerja peningkatan kesejahteraan pekerja melalui pendalaman pemahaman MESOP, 
penelusuran mekanisme pelaksanaan MESOP, serta studi banding kepada perusahaan yang telah menjalankan program MESOP dan berhasil meningkatkan kesejahteraan pekerja melalui kepemilikan saham.

Sebagai pengurus Serikat Pekerja peran sosialisasi melalui penyuluhan mengenai program MESOP ini banyak memberikan informasi baik bagi Pengurus Serikat Pekerja di Perusahaan, maupun Pengurus Serikat Pekerja Cabang Kabupaten Karawang umumnya sehingga mereka termotivasi untuk lebih fokus pada peningkatan kesejahteraan pekerja melalui program MESOP ini, dengan cara melalukan dialog secara terbuka dengan pihak perusahaan dan menungkannya dalam bentuk Perjanjian Kerja Bersama (PKB).

\section{KESIMPULAN DAN SARAN \\ Kesimpulan}

Sosialisasi yang telah diberikan melalui kegiatan Pengabdian Kepada Masyarakat telah menambah pengetahuan dan pemahaman peserta yaitu Pengurus Serikat Pekerja terhadap Program MESOP dalam meningkatkan partisipasi kepemilikan dan kesejahteraan pekerja sehingga hasil sosialisasi ini dapat bermanfaat dan meningkatkan kesadaran pengurus serikat pekerja sehingga termotivasi bahwa peningkatan kesejahteraan bukan saja melalui kenaikan upah dan perjuangan pesangon bagi pekerja yang di PHK saja, ada banyak program kesejahteraan lainnya yang dapat diperjuangkan serikat pekerja antara lain melalui kepemilikan saham oleh pekerja / MESOP.

\section{Saran}

Kami menyarankan pengurus serikat pekerja memiliki keberanian untuk duduk bersama dengan pihak perusahaan dalam upaya meningkatkan kesejahteraan pekerja melalui program kepemilikan saham yang telah diatur dalam hk perusahaan dan hukum ketenagakerjaan, baik itu berupa pembelian saham oleh pribadi pekerja, berupa insentif, atau bonus yang diberikan oleh perusahaan, dan dituangkan dalam Perjanjian Kerja Bersama yang dibuat oleh Serikat Pekerja dan Perusahaan sehingga memiliki kekuatan hukum bagi kedua belah pihak.

\section{DAFTAR PUSTAKA}

Andi Fariana, Aspek Legal Sumber Daya Manusia Menurut Hukum Ketenagakerjaan, Jakarta: Mitra Wacana Media, 2012

Backy Krisnayuda, Pancasila dan Undang-undang, Relasi dan Transformasi Keduanya dalam Sistem Ketatanegaraan Indonesia, Edisi Pertama, Cetakan Ke-1, Prenamedia Group, Jakarta, 2016

Deviany Siswani Anggrawan, Pengaruh ESOP terhadap KInerja Perusahaan Publik di Indonesia, Petra Business and Management Review, Volume 2, Nomor 2, Tahun 2016

Sayid Mohammad Rifqi Noval, Hukum Ketenagakerjaan, Bandung: Refika Aditama, 2017. 